\title{
Calcium Release from the Skeletons of Rachitic Puppies
}

\author{
JENIFER JOWSEY \\ From the Mayo Clinic and Mayo Foundation: Orthopedic Research Laboratory, \\ Rochester, Minnesota 55901
}

A в S T RAC T The experiment was carried out on 3-month old puppies. Control animals received a diet normal in calcium and vitamin $\mathrm{D}$. The diet for one group of experimental animals was deficient in both calcium and vitamin $\mathrm{D}$, while another experimental group was fed a diet deficient in calcium but with adequate vitamin $D$. The response of these animals to injected parathyroid extract was evaluated over a 4 month period. The serum calcium response fell after approximately 20 days in both the calcium-deficient (vitamin D-replete) and the calcium- and vitamin D-deficient animals. The effect on the parathyroid response of the addition of calcium or vitamin $\mathrm{D}$ in vitamin $\mathrm{D}$ - and calcium-deficient animals was also evaluated. The addition of vitamin $\mathrm{D}$ to rachitic animals did not restore the response to parathyroid extract; however, in calciumand vitamin D-deficient animals with normal calcium levels there was a restored response to parathyroid extract. Morphologic studies were made of the bone at various times during the experimental period; the presence of osteoid tissue correlated with the absence of a response to injected parathyroid extract. The results suggest that parathyroid hormone acts independently and requires the presence of mineralized bone for its action in raising the serum calcium. Vitamin D appears to be important in the mineralization of new bone tissue.

\section{INTRODUCTION}

A controversy has existed for some time over the importance of vitamin $\mathrm{D}$ in the action of parathyroid hormone $\left(\mathrm{P}^{\prime} \Gamma \mathrm{H}^{1}\right)$ on bone. One group of investigators support the view that in order for PTH to increase bone resorption and release calcium into the blood, vitamin D must be present (1-3). On the other hand, Albright and Reifenstein (4) suggested that the envelope

Received for publication 7 May 1971 and in revised form 13 August 1971.

1 Abbreviations used in this paper: PTE, parathyroid extract; PTH, parathyroid hormone. of unmineralized osteoid tissue that develops in vitamin D-deficient animals is the critical factor which results in the failure of $\mathrm{PTH}$ to raise the serum calcium by preventing exchange of calcium ions between extracellular fluid and bone. The present report demonstrates that the presence of osteoid tissues is probably the most important factor, although the morphologic data suggest that it is the resorption of the unmineralized osteoid, rather than ion exchange through it, that is important.

\section{METHODS}

\section{Experimental groups}

These studies were carried out on four litters of puppies approximately 3 months old at the beginning of the experiment; each litter was divided into three main groups and the animals were pooled from each litter.

\section{Diet}

Group 1, the controls, consisted of animals fed a diet normal in calcium and vitamin D. In group 2, the animals were deficient in both calcium and vitamin D, and in group 3 the animals were deficient only in calcium. In all three groups the basic diet was both calcium-deficient and vitamin D-deficient (5); however, the first group and the third group had vitamin D added at a level of 10 USPU/ $\mathrm{kg}$ per day in the food and $10 \mathrm{USPU} / \mathrm{kg}$ which was injected subcutaneously every day (equivalent to 12,600 USPU/wk in an adult man) and group 1 also had calcium added at a level of $40 \mathrm{mg} \mathrm{Ca} / \mathrm{kg}$ per day. The diets were fed for 4 months, at which time the puppies became adult and were killed.

\section{Parathyroid hormone test}

The serum calcium, phosphate, and alkaline phosphatase were followed at approximately fortnightly intervals; at these times, parathormone ${ }^{2}$ (PTE, parathyroid extract) was injected intravenously, $40 \mathrm{USPU} / \mathrm{kg}$ body wt, immediately after a base line blood sample had been drawn. A second blood sample was taken $4 \mathrm{hr}$ later, at which time at this dose the maximal serum calcium level is reached. The calcium levels and, in the terminal studies, the phosphate levels were measured in both the 0 and 4-hr blood samples. The response to PTE shown by the rise in the serum calcium to this standard amount of hormone at 4

${ }^{2}$ Eli Lilly \& Co., Indianapolis, Ind. 


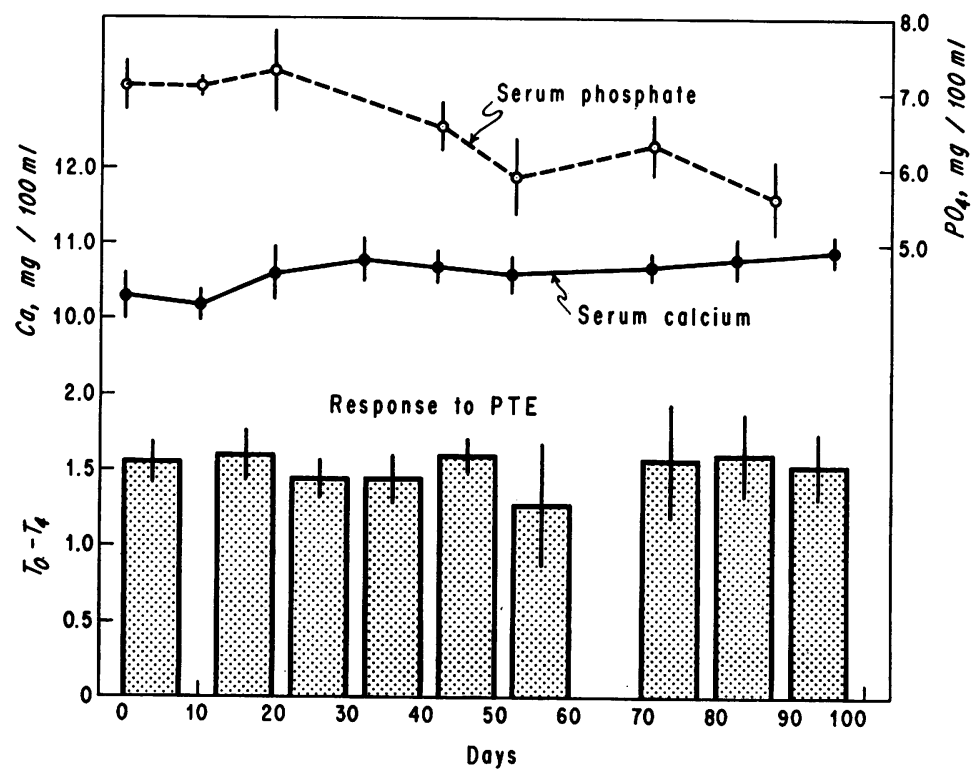

FIgURE 1 Serum calcium and phosphorus levels and serum calcium response to $40 \mathrm{USP} \mathrm{U} / \mathrm{kg}$ of $\mathrm{PTE}$ in control puppies given calcium and vitamin $\mathrm{D}$ : group 1 .

hr was called the $T_{0}-T_{4}$ test and is labeled as such on the graphs.

Bone biopsies of the midshaft of the ulnas were taken 1 and 2 months after starting the experimental diet. The levels of bone resorption and the amount of bone surface covered by osteoid were measured in calcified sections made from undemineralized sections and from microradiographs $(5,6)$. Roentgenograms were made of the knees and the jaws when the animals were killed.

Since the development of rickets is associated with secondary hyperparathyroidism, it was necessary to eliminate this as a factor in the response to PTH. For this reason, a group of six puppies was thyroparathyroidectomized after 1 month on a calcium-deficient and vitamin $\mathrm{D}$-deficient diet, and the $T_{0}-T_{4}$ test was repeated for 4 days.

\section{Attempts to restore response to PTE}

The addition of vitamin $D$. In two groups of vitamin Ddeficient and calcium-deficient rachitic puppies, vitamin D was given subcutaneously at levels of 20 or $100 \mathrm{USPU} / \mathrm{kg}$ per day for a period of 10 days, and the $T_{0}-T_{4}$ test was



Figure 2 Serum calcium and phosphorus levels and serum calcium response to $40 \mathrm{USP} \mathrm{U} / \mathrm{kg}$ of PTE in calcium- and vitamin D-deficient puppies : group 2. 


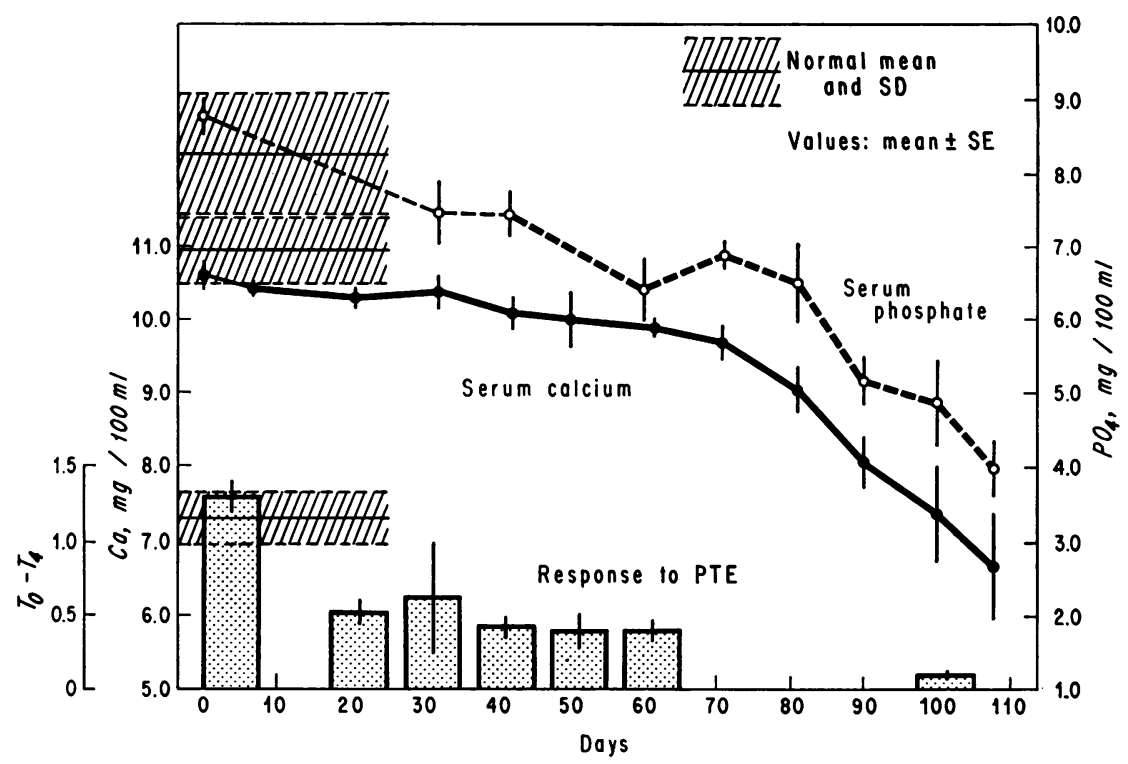

FIGURE 3 Serum calcium and phosphorus levels and serum calcium response to 40 USP $\mathrm{U} / \mathrm{kg}$ of PTE in calcium-deficient puppies: group 3 .

repeated at 5-day intervals. In addition, vitamin $D$ was given for 10 days to four puppies who had been on the diet for 1 month and had developed a reduced $T_{0}-T_{4}$ response but whose serum calcium and phosphorus values were still normal.

The addition of calcium. One group of vitamin D-deficient and calcium-deficient rachitic puppies was given calcium, $120 \mathrm{mg} / \mathrm{kg}$ ( $80 \mathrm{mg} / \mathrm{kg}$ subcutaneously per day in two divided doses and $40 \mathrm{mg} / \mathrm{kg}$ orally). Their response to the $T_{0}-T_{4}$ test was measured every 5 days for 30 days.

\section{RESULTS}

The control animals showed an unaltered level of serum calcium and a slight fall in serum phosphorus which is characteristic of puppies as they achieve skeletal maturity. The response to PTE was unchanged throughout the experimental period (Fig. 1). The animals fed the diet which was deficient in calcium and vitamin $\mathrm{D}$ had a sharp fall in serum calcium after approximately 30 days, followed by a more gradual fall in the phosphorus. The serum calcium response to PTE fell after 20 days when the serum calcium and phosphorus were normal and remained low for the remainder of the experimental period (Fig. 2). In the absence of calcium but in the presence of vitamin $\mathrm{D}$ there was a decrease in both the serum calcium and phosphorus levels which occurred at 80-90 days, while a failure to respond to PTE occurred after 20 days when the serum calcium and phosphorus were still normal (Fig. 3 ). In comparison to the animals that were both calcium-deficient and vitamin D-deficient, the fall in the serum levels was slower but the failure to respond to PTE occurred at the same time. The terminal serum calcium phosphate and alkaline phosphatase levels were the same in the last two groups and were different from the values in the control animals (Table I). Also, both the calcium-deficient and the calcium-deficient and vitamin D-deficient animals had widening of the epiphyseal plate and loss of the lamina dura adjacent to the teeth (Fig. 4).

As a result of parathyroidectomy (after 30 days on a calcium-deficient and vitamin D-deficient diet) the serum calcium fell (Table II). The calcium response to PTE was unchanged both $1 \mathrm{hr}$ and 3 days after parathyroidectomy. The serum phosphorus response to PTE fell slightly immediately after parathyroidectomy, and 3 days after parathyroidectomy there was a negative response rather than a rise (Table II).

\section{Attempts to restore PTE response}

The addition of vitamin $D$. In rachitic calcium-deficient and vitamin D-deficient animals with a lowered response to PTE and low serum calcium and phosphorus

TABLE I

Terminal Serum Values* in the Three Groups of Puppies

\begin{tabular}{lcccc}
\hline & \multicolumn{2}{c}{ Serum } & \\
\cline { 2 - 4 } \multicolumn{1}{c}{ Group } & Calcium & $\begin{array}{c}\text { Phos- } \\
\text { phorus }\end{array}$ & & $\begin{array}{c}\text { Alkaline } \\
\text { phosphatase }\end{array}$ \\
\hline & $m g / 100 m l$ & $m g / 100 ~ m l$ & King-Armstrong $U$ \\
$\begin{array}{l}\text { 1, control } \\
\begin{array}{l}\text { 2, low Ca, } \\
\text { low vitamin D }\end{array}\end{array}$ & $10.8(0.42)$ & $5.9(1.03)$ & $12.4(15.1)$ \\
$\begin{array}{l}\text { 3, low Ca, } \\
\text { high vitamin D }\end{array}$ & $6.9(0.65)$ & $5.3(0.36)$ & $46 \quad(14.8)$ \\
\hline
\end{tabular}

* Values are the mean \pm 1 SD (in parentheses). 

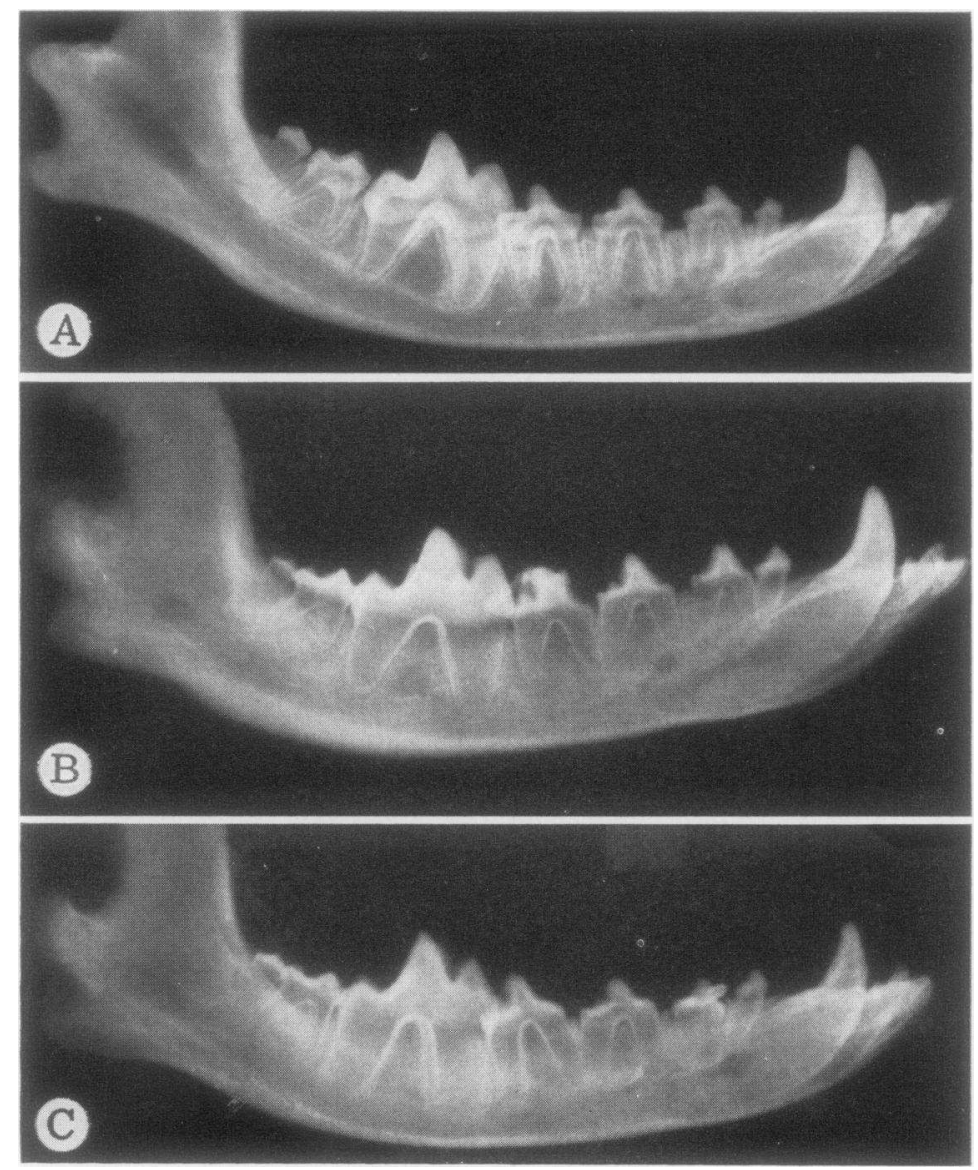

FIgure 4 Jaws and teeth in puppies of group 1: $A$, Given calcium and vitamin $\mathrm{D}$; group $2: B$, Deficient in calcium and vitamin $\mathrm{D}$; and group 3: $C$, Deficient in calcium but given vitamin $\mathrm{D}$. In $B$ and $C$ there has been loss of the lamina dura.

levels, the addition of vitamin D, 20 or $100 \mathrm{USPU} / \mathrm{kg}$, did not alter the response to PTE (Figs. 2 and 3 ). However, in animals in which the response to PTE had fallen but in which the serum calcium and phosphorus was still normal after 10 days of vitamin $\mathrm{D}$, the response to PTE rose to within the normal range (Table III). This effect was not accompanied by a change in resting serum calcium or phosphorus values.
The addition of calcium. The addition of calcium, subcutaneously and in the diet, caused a clear rise in the serum calcium and a fall in phosphorus, while the response to PTE rose slightly but never became normal (Table III). Radiographs of the knee made at this time showed a partial calcification of the epiphyseal plate in the treated puppies, compared with the pretreatment X-ray.

TABLE II

Response to Parathyroidectomy in Calcium-and Vitamin D-Deficient Puppies

\begin{tabular}{|c|c|c|c|c|}
\hline \multirow[b]{2}{*}{ Period } & \multicolumn{2}{|c|}{ Serum } & \multirow[b]{2}{*}{$\mathrm{Ca} T_{0}-T_{4}$} & \multirow[b]{2}{*}{ PO, $T_{0}-T$} \\
\hline & $\mathrm{Ca}$ & PO، & & \\
\hline & $m g / 100 m l$ & $m g / 100 m l$ & $m g / 100 m l$ & $m g / 100 m l$ \\
\hline Before surgery & $10.0(0.2)^{*}$ & $6.3(0.3)$ & $0.4 \quad(0.1)$ & $1.3(0.2)$ \\
\hline $2 \mathrm{hr}$ after surgery & $9.4(0.2)$ & $6.2(0.1)$ & $0.25(0.2)$ & $0.8(0.2)$ \\
\hline 3 days after surgery & $4.2(0.1)$ & $6.6(0.1)$ & $0.4 \quad(0.2)$ & $-0.8(0.4)$ \\
\hline
\end{tabular}

* Values are the mean $\pm 1 \mathrm{SD}$ (in parentheses). 
TABLE III

Response to Treatment with Vitamin D and Calcium

\begin{tabular}{|c|c|c|c|c|}
\hline \multirow[b]{2}{*}{ Period } & \multicolumn{2}{|c|}{ Serum } & \multirow[b]{2}{*}{$\mathrm{Ca}_{\mathrm{T}} \mathrm{T}_{0}-\mathrm{T}_{4}$} & \multirow[b]{2}{*}{ PO, $T_{0}-T_{1}$} \\
\hline & $\mathrm{Ca}$ & $\mathrm{PO}_{4}$ & & \\
\hline & $m g / 100 m l$ & $m g / 100 m l$ & $m g / 100 m l$ & $m g / 100 m l$ \\
\hline Before vitamin D & $10.1(0.4)^{*}$ & $6.7(0.5)$ & $0.5(0.2)$ & $0.9(0.1)$ \\
\hline $1-2$ days of vitamin $D$ & $10.3(0.1)$ & $6.7(0.4)$ & $1.2(0.5)$ & $1.1(0.2)$ \\
\hline $6-10$ days of vitamin $D$ & $10.5(0.2)$ & $7.1(0.5)$ & $1.2(0.4)$ & $1.1(0.3)$ \\
\hline Before calcium & $6.7(0.4)$ & $6.2(0.5)$ & $0.2(0.2)$ & - \\
\hline 15 days of calcium & $8.2(0.3)$ & $5.0(0.3)$ & $0.2(0.2)$ & 0.3 \\
\hline 30 days of calcium & $9.4(0.3)$ & $4.3(0.4)$ & $0.6(0.3)$ & 0.1 \\
\hline
\end{tabular}

*Values are the mean $\pm 1 \mathrm{SD}$ (in parentheses).

\section{Measurements on bone biopsies}

The length of unmineralized osteoid tissue in the biopsies from the puppies after 1 month on the diet deficient in calcium and vitamin $\mathrm{D}$, as well as those on the diet deficient in calcium alone, showed an increase in the amount of both osteoid tissue and resorption (Table IV, Fig. 5). On the diet deficient in calcium the increase was less marked. By 2 months the osteoid and resorption had further increased in both groups; the osteoid tissue was clearly wider. In the calcium- and vitamin D-deficient group the majority of the bone surfaces were occupied by either resorption or formation.

As a result of parathyroidectomy the amount of osteoid tissue did not change while bone resorption decreased. With the administration of vitamin $D$ the amount of osteoid tissue decreased to less than normal while bone resorption increased. After 30 days of calcium administration the osteoid had increased (Table IV).

\section{DISCUSSION}

The data show clearly that rickets can be produced in puppies in the presence of vitamin D if calcium is absent from the diet. This has previously been observed by Campbell and Douglas (7). In our study the rickets was grossly evident in the radiographs of the knees and jaws, in the serum changes, and in the bone biopsy. Rickets took longer to develop if vitamin D was present, presumably because small amounts of calcium were absorbed in the gut. The failure of the parathyroids to maintain serum calcium levels terminally presumably was due to the morphologic state of the bone, which was largely occupied by osteoid resorption. Vitamin D was not able to prevent the fall in serum calcium or the development of rickets. In contrast, rickets has not been successfully produced in rats in the presence of vitamin D (3). It is probably for this reason that the majority of the studies in vitamin $\mathrm{D}$-deficient rats have not distinguished between the effect of vitamin $D$ on the gut and the effect of vitamin D on the bone-parathyroid hormone relationship, so that many authors have ascribed a permissive effect of vitamin D to PTH action when it is given to vitamin $\mathrm{D}$-deficient animals.

However, a number of studies have suggested that the action of PTH in raising the serum calcium is independent of vitamin D. An independent action of PTE has been reported by Toverud in mice (8), Sevastikoglou, Ray, Hjertquist, and Bergquist in rats (9), Hertelendy and Taylor in fowls (10), and Ney, Au, Kelly, Radde, and Bartter in puppies (11). In the last report, the success of PTE in raising the calcium was proportional to the initial serum calcium values, suggesting that the more rachitic the animal the greater the failure of action of $\mathrm{PTH}$, or conversely that the less vitamin D-deficient animals responded to PTE.

TABLE IV

Osteoid Surface and Resorption Surface in Untreated and Treated Puppies

\begin{tabular}{|c|c|c|}
\hline Group & $\begin{array}{l}\text { Osteoid } \\
\% \text { surface }\end{array}$ & $\begin{array}{c}\text { Resorption } \\
\% \text { surface }\end{array}$ \\
\hline Control, group 1 & $8.4(1.9)^{*}$ & $6.7(1.7)$ \\
\hline \multicolumn{3}{|l|}{$\begin{array}{l}\text { Calcium- and vitamin D- } \\
\text { deficient diet, group } 2\end{array}$} \\
\hline 1 month & $32.5 \quad(6.6)$ & $20.3(1.6)$ \\
\hline 2 months & $61.6 \quad(8.4)$ & $27.3(4.4)$ \\
\hline \multicolumn{3}{|l|}{$\begin{array}{l}\text { Calcium-deficient diet, } \\
\text { group } 3\end{array}$} \\
\hline 1 month & $25.3 \quad(3.3)$ & $11.7(1.4)$ \\
\hline 2 months & $52.7 \quad(7.7)$ & $20.3(8.3)$ \\
\hline \multicolumn{3}{|l|}{ Rachitic puppies } \\
\hline Parathyroidectomized & $29.3 \quad(5.8)$ & $9.0(2.0)$ \\
\hline Treated with calcium & $55.5(15.3)$ & - \\
\hline Treated with vitamin $\mathrm{D}$ & $3.9(0.7)$ & $29.9(7.8)$ \\
\hline
\end{tabular}

* Values are the mean \pm 1 sD (in parentheses). 


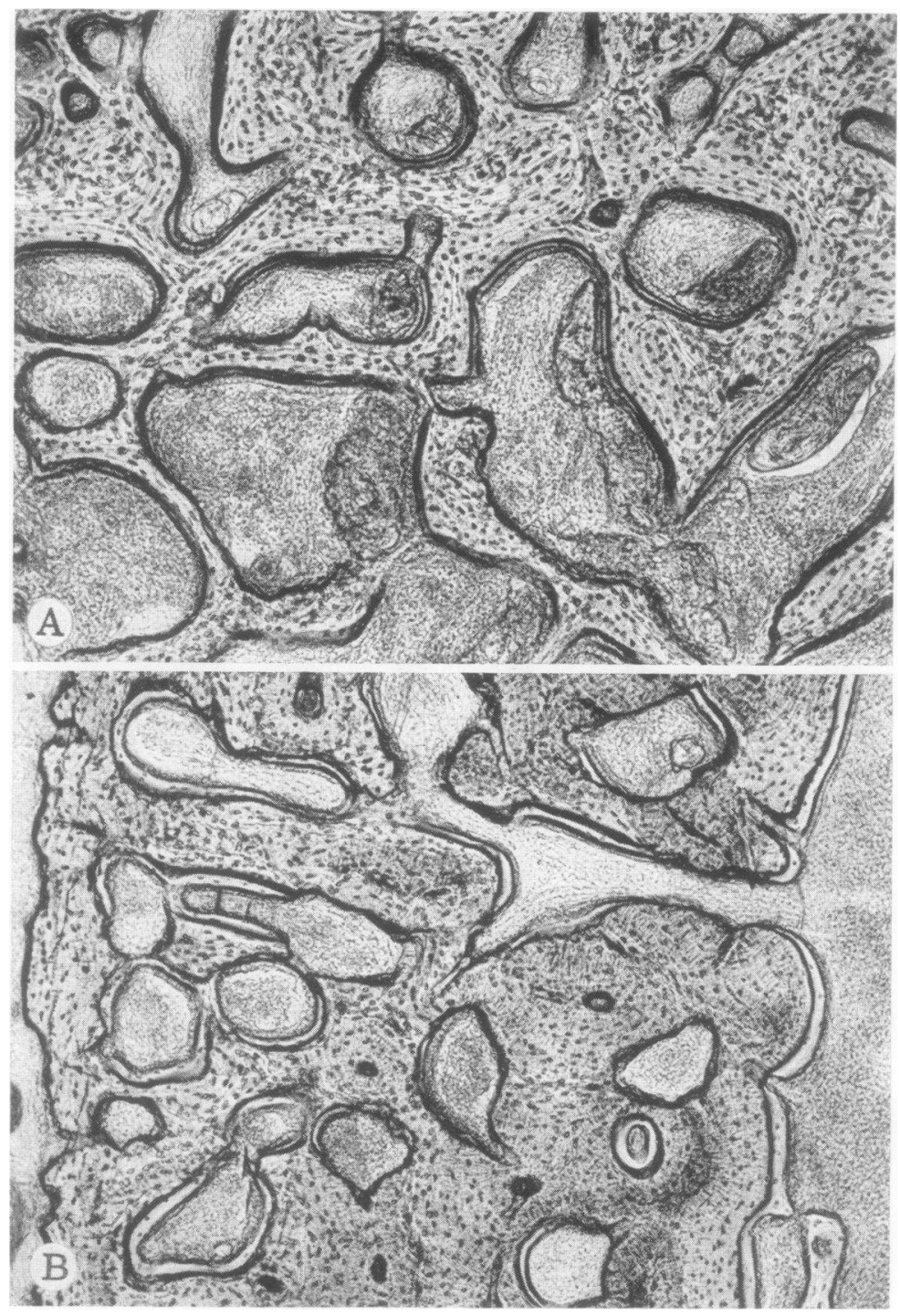

Figure $5 A$, Bone biopsy from a calcium- and vitamin D-deficient puppy at 1 month; many surfaces are covered by unmineralized osteoid tissue. $B$, Bone biopsy from calcium- and vitamin $\mathrm{D}$-deficient puppy at 2 months; the unmineralized osteoid tissue is wider. $(\times 80)$.

In both this study and in others, therefore, the major criticism has been that the animals still contain small amounts of vitamin $\mathrm{D}$ which permit the action of the administered PTE. The study reported here has the advantage of approaching the problem from the other direction, observing the failure of PTE to work in the presence of vitamin $\mathrm{D}$. That the failure to respond to PTE did not result from repeated administration of the extract was shown by the control group which continued to respond normally throughout the experiment. Neither did the failure depend on an endogenous increase in PTH secretion in the puppies. Ney et al. (11) demonstrated a fall in phosphorus clearance after para- thyroidectomy which suggested that endogenous PTH was increased in their puppies as it must have been in groups 2 and 3 reported here. However, any increase in endogenous hormone that had occurred failed to account for the decreased response, since the rachitic puppies did not show a return toward a normal response to PTE after parathyroidectomy.

The responses of the vitamin $\mathrm{D}$-injected and vitamin $D$-fed rachitic puppies would seem to establish firmly that the action of parathyroid hormone on bone is not related to the presence or absence of vitamin $\mathrm{D}$, while the bone morphology studies would suggest that the unmineralized osteoid is important. Presumably, the osteoir 
covers the bone and makes mineralized tissue inaccessible for resorption; osteoclastic destruction of osteoid is rare and generally only occurs in disorders characterized by unusually active bone resorption. When it does occur it obviously does not result in any increase in the serum calcium value. The fact that vitamin $D$ failed to restore the response to PTE seems to show that it is not permissive for the action of $\mathrm{PTH}$. In animals in which biochemical rickets had not yet developed, vitamin $\mathrm{D}$ did restore the response to PTE, a result similar to that described in rats. This may have resulted from an increased intestinal absorption of calcium; the measurements on the bone biopsies showed that vitamin $D$ reduced the amount of osteoid tissue covering bone surfaces to normal. Therefore, although there was probably also an effect on intestinal resorption, a restoration of PTE action could be explained by the return of the bone tissue to normal mineralization.

Au and Raisz (12) found that parenteral calcium did restore the response to parathyroid extract in rats. In puppies, complete restoration of the response was not achieved in rachitic animals despite a rise to near normal values for the serum calcium. The layer of osteoid on the surface of bone which remained, and even increased, in these animals suggested that bone was unresponsive. The success of vitamin $\mathrm{D}$ in restoring the PTE response in unresponsive but nonrachitic puppies also suggests the state of mineralization of the bone to be the important factor; vitamin $\mathrm{D}$ dramatically decreased the surface area covered by osteoid and consequently restored the response to PTE. The rise in resorption reflects the effect of PTE.

In puppies, vitamin $\mathrm{D}$ appears to increase the mineralization of new bone tissue, possibly by transferring mineral from the serum into the bone. Parathyroid hormone appears to act independently and requires for its calcium-raising action only the presence of mineralized bone tissue.

\section{ACKNOWLEDGMENTS}

This investigation was supported in part by Research Grant AM-8658 from the National Institutes of Health, Public Health Service.

\section{REFERENCES}

1. Harrison, H. C., H. E. Harrison, and E. A. Park. 1958. Vitamin D and citrate metabolism: effect of vitamin D in rats fed diets adequate in both calcium and phosphorus. Amer. J. Physiol. 192: 432.

2. Rasmussen, H., H. Deluca, C. Arnaud, C. Hawker, and M. von Stedingk. 1963. The relationship between vitamin $\mathrm{D}$ and parathyroid hormone. J. Clin. Invest. 42: 1940.

3. Arnaud, C., H. Rasmussen, and C. Anast. 1966. Further studies on the interrelationship between parathyroid hormone and vitamin D. J. Clin. Invest. 45: 1955.

4. Albright, F., and E. C. Reifenstein, Jr. 1948. The Parathyroid Glands and Metabolic Bone Disease. Selected Studies. The Williams \& Wilkins Co., Baltimore. 206.

5. Kelly, P. J. 1967. Bone remodeling in puppies with experimental rickets. J. Lab. Clin. Med. 70: 94.

6. Jowsey, J. 1966. Quantitative microradiography: a new approach in the evaluation of metabolic bone disease (editorial). Amer. J. Med. 40: 485.

7. Campbell, J. R., and T. A. Douglas. 1965. The effect of low calcium intake and vitamin $D$ supplements on bone structure in young growing dogs. Brit. J. Nutr. 19: 339.

8. Toverud, S. U. 1964. The effect of parathyroid hormone and vitamin D on serum calcium in rats. Acta Physiol. Scand. 62: 391.

9. Sevastikoglou, J. A., R. D. Ray, S.-O. Hjertquist, and E. Bergquist. 1970. Vitamin D and skeletal metabolism: experimental studies in the rat. Acta Orthop. Scand. 136(Suppl.) : 4.

10. Hertelendy, F., and T. G. Taylor. 1960. On the interaction between vitamin $\mathrm{D}$ and parathyroid hormone in the domestic fowl. Biochim. Biophys. Acta. 44: 200.

11. Ney, R. L., W. Y. W. Au, G. Kelly, I. Radde, and F. C. Bartter. 1965. Actions of parathyroid hormone in the vitamin D-deficient dog. J. Clin. Invest. 44: 2003.

12. Au, W. Y. W., and L. G. Raisz. 1967. Restoration of parathyroid responsiveness in vitamin $D$-deficient rats by parenteral calcium or dietary lactose. J. Clin. Invest. 46: 1572. 